\section{SOI: 1.1/TAS DOI: $10.15863 /$ TAS International Scientific Journal Theoretical \& Applied Science}

\author{
p-ISSN: 2308-4944 (print) e-ISSN: 2409-0085 (online) \\ Year: $2016 \quad$ Issue: 11 Volume: 43 \\ Published: 02.11.2016 http://T-Science.org
}

Manzura Omanbayevna Otajanova

$\mathrm{PhD}$

Senior Scientific Researcher of Research Institute of

Uzbek Language and Literature under the Tashkent State University of Uzbek Language and

Literature gulom1208@gmail.com

SECTION 29. Literature. Folklore. Translation Studies.

\title{
NEW APPROACH TO THE TRADITIONS
}

Abstract: Myth-story genre is arisen as a specific myth poetic occurrence in the result of investigations in modern Uzbek prose, it is considered sincerity result of mythological and literary thought and it is analyzed in basis of myth-story "Oxir zamon nishonalari" by Chingiz Aytmatov. Besides it, styles of mytho-ritual, mythoexistential are widely used to artistically implement the peculiarities of surrender and humanity. In this paper the myth is being reiteratively interpreted as a basic and inseparable element of national artistic mentality. This is why cases of origination of new genres as "novelmyth" and "story-myth" should be explicated as researches on national identification of artistic mentality by means of mythological modeling of the authors in the literal studies are analyzed by author.

Key words: folklore, myth-story, syncretism, novel-myth, mythic-symbolic phrases.

Language: English

Citation: Otajanova MO (2016) NEW APPROACH TO THE TRADITIONS. ISJ Theoretical \& Applied Science, 11 (43): 8-12.

Soi: $\underline{\text { http://s-o-i.org/1.1/TAS-11-43-3 Doi: crossef http://dx.doi.org/10.15863/TAS.2016.11.43.3 }}$

\section{Introduction}

Due to the historical development and reiterative poetic interpretation transformation of myths and events myths had become a solid and fruitful background to the folklore, whereas, in its turn, folklore had become the same to the written literature. Researches on influence of folklore to the written literature and affection of literature to the folklore, their mutual beneficiation had become one of important directions in the literal studies. If to look wider, we can state that a nowadays person's mentality embraces rudiments of the ancient times up to the contemporary concepts to some certain extend. Having been harmonized in accordance with our consciousness they provide outcome of the present mentality.

Majority of people state and remain attached to the view that the myths appeared due to impuissance of the humanity against nature. In our opinion, myths and their affects are still vivid as they are not representation of imoussance of humanity against nature, indeed, representation of their assurance in own puissance and assurance that eternity to overwhelm malice.

\section{Materials and Methods}

Analysis of the works of the nowadays Uzbek literature indicate that, one can notice aspiration to utilize universal archetype models, characters and motives created on the basis of mythological apprehension of the world as well as construction of the literal work on the basis of mythological implication had become a main reason in origination of the counterpoint polyphonism in the style of presenting an imagined reality by the author.

Usage of the mythopoetic traditions in the course of description of the reality within the works, in its turn, results harmonization of realistic and symbolical-metaphoric interpretation as well as harmonized provision of mythicsymbolic phrases along with unoculation of chronotropic direction and mythic views peculiar to archaic mentality into the described world.

We can evidence a myth to become a vital poetic means for the works created from the early XX century up to the present time. Cases as intervention of a myth into the subject or its mythic resolution, harmonization of the mythic views along with work's essence either representation of the imaginative ideas in the myth oriented condition have become peculiar to the modern novels. It is known that «ancient people's views about space, thoughts on natural 
events, and fantasies in their mind do present a myth» [7, p. 198]. They have appeared as a result of our ancestor's requirements in apprehension, acceptation and establishment of relations with the reality.

Utilization of a myth, which happens to be an example of folklore, within a written literature is not a novelty in the history of literature development. Hence "If expression is admissible, a myth used to be a "conventional garment" of the time in the literature of the past» [6, p. 3]. But utilization and function of a myth in the modern literature had been fundamentally changed in accordance with authors' poetic aims and readers' mentality in regards to worldapprehension. «In the modern literature, especially under the pen of the western authors, a myth had obtained a "historical image" of "consequence" illustrating regularities of a long past reiteratively repeated throughout people's life, had been apprehended separately and studied independently» [6, p. 3]. In this context we can underline three conditions a myth's function in the modern literature: First, apprehension of a myth as consequence of regularities reiteratively repeated in human's life. In point of fact, when we look through the examples of world literature, we notice that myths, encountered in the imaginative literature, come for the assistance in the points for resolution and clarification of the most important, reiteratively repeated and ongoing views related to the destiny of humanbeing. - We shall try to comment our opinion in the example of eminent Kyrgyz men-of-letters Chingiz Aytmatov's «Ohir zamon nishonalari» (Yields of the last day) («Casandra's curse»).

In the novel "Ohir zamon nishonalari», views and warnings on humanity being at the critical point, beings at the edge of calamity, facing nuclear, ecological, social and other major issues are realized by means of a myth. Moreover, genetic challenges being encountered by the humanity, especially, perturb the scientists. The main idea of the novel is that the most actual challenge of the life is its fullness of challenges towards not only newly born careless offsprings, but as well as children within attentive families. Possibilities that ruthless tragedies may put a life of the generation under danger, whereas the most awful, new generation is being born accustomed to it, carriage of it in its gens becoming a huge social danger, while its remedies are still unknown - in the process of resolution of these problems an author refers interference of a myth into the written literature. Warning humanity on the forthcoming disasters, an author uses a creature of the main hero Philofey named as predictor Cassandra: «There is only one remedy, which is Cassandra listens to the implications of the embryos on the apocalypse and making conclusion and suggestions on necessity in perfection of the society, particularly, each of its members», notes Philofey [1, p. 189].

Secondly, availing historical aspect due to being a consequence of a long history. It is essential to consider myth's genre style as myths are the results of peoples' barbaric imaginations about ancient period. At the emergency situations people recall their past, refer to their experience and avail lessons. Utilization of a myth in the novels covering disputes on the actual challenges on time, person, public and eternity can be justified by this exactly. In the «Ohir zamon nishonalari» novel also, Philofey evaluates own actions and beliefs in correlation with Cassandra's activities and destiny, and tries to reveal lessons from those events: «I am in panic in front of my fate made by myself - what will happen to humanity, how people of tomorrow, their mentality and soul will accept Cassandra's curse? Whatever happens, damned truth will never become veracity. A challenge ignored today will be encountered tomorrow; one will not be able to get rid of it in any ways» [1, p. 197].

It is known that as per Greek mythology, after rejection Apollo's love, Cassandra had been damned, and her predictions would have never been trusted by anyone. How about Philofey's predictions? Why they had been damned by the public? Philofey evaluates own actions as «damned truth». But his predictions, which were rejected by the public, remind eremitic Cassandra's destiny - disbelieved predictions by the public. This paradox strengthens Philofey's conclusion on the results of his scientific researches: he renounces from implementation of his creature, whereas sentences himself for the disaster. The ideological aspect of the works stipulates that the roots of the human challenges cannot be limited by bounders of history and time.

Thirdly, being apprehended independently. In the modern novels myths are referred with amendments of their ideological aspect, sometimes their general structure as well as their social-literal and philosophical function. Author refers to a myth in his literal aim. There are several important poetic purposes of the author in bringing Cassandra's developments into «Ohirgi zamon nishonalari».

It is known that appearance of a concept of myth is mainly justified by impuissance of our ancestors against natural occurrences and inabilities to find real facts to comment natural regularities. For example, myths were created by people who could not justify the reasons of such occurrences as earthquake, sunset, plenilune and 
etc. «For instance, a megaseism is justified with movement of a magma in the entrails of the ground occurs - which could not be asserted by poor people, logically, they would imagine that an earth is being carried by a bull, which results to its quake» $[4$, p. 20]. Reference to a myth on contemporary literature is justified with the same reasons. I.e., scientifically unjustified and could not be explained puzzles are resolved by means of a myth. Thus, these both genres, notwithstanding one being a folklore and another to be a written literature - do represent interrelation between both of them in their origination. May be due to this aspects authors of nowadays novels do feel necessity in reference to a myth.

There are adherents a myth to originate a religion. «Mythology's aspect related to social mentality avail a very complicated character. For example, if few scientists comment myth and religion as one unique apparition, others underline myth to avail a religious character during a particular stage of its development» $[7$, p. 199]. There is some reference to the same in Russian Writer, Lev Tolstoy's "Confession". Speaking about a religion precisely, a man-ofletters states that those issues unable to be resolved by humanity either science can be justified through a religion.

Logically, whenever novelists are unable to locate a precise, real and scientific resolution of the issue raised - they refer to a myth which descends for the solution.

It is known that scientific works require a precise resolution of the thoughts, views and challenges being described. As well as modern intellectual novels in this context pretend to follow a scientific direction, i.e., presents scientific conclusion and resolution of the events and scientific inventions. But in the imaginative literature this resolution cant avail a real background. May be in this regard authors of the nowadays novels undergo through a fantastic description or refer to a myth in majority of cases. Otherwise samples of imaginative literature would not differ from a scientific work. In «Ohir zamon nishonlari» also a author searches resolutions for the challenges encountering, but locates representation of them by heavenly almighty's miracles rather than lifereal and precise facts. Probably author's circle of contradictions turned so large that he implies to those possibilities to tackle them from-under foot remain less and less.

Moreover, another reason for reference to a myth within social novels can be commented by literal work's regular function. Myth serves for imaginative interpretation of literal reality, as well as for literal justification of hero's actions, activities and mental-spiritual world. Thinking over his predictions being collapsed, Philofey recalls Cassandra's destiny and locates similarities between his own and Cassandra's faith: «...damned truth will never become veracity» [1, p. 197]. Such conclusion of Philofey on his own actions can also be considered as mythic view. For example, evaluation of events as "not to spit in the water", "to see white for good", "to see black for bad" is also a result of a mythic imaginations. Along with this, we can evidence roots of mythological views in impression of a novel hero Robert Bork, futurologist over whales distress, overwhelming particular mental feelings due to their actions and observing this distress as implication to a specific tragedy. Moreover, provision of stories about an owl appearing in the Red square along with parallel indication of predictions related to warnings on tragedies - is the very similarity on the nation's barbaric views on predicting sorrowful tragedies.

Men-of-letters comment origin of a myth as a consequence of fantasies and imaginations in the aspiration of humanity towards science, requirements nad appearing of advanced ambitions. I.e, there were adherents to consider a myth as an intellectual event of an advanced degree. As from the initial stage of humanity's aspiration towards science - myths encouraged humanity towards practical activities as to think, to locate differences and similarities in the events, compare, generalize, to conclude and logically estimate - as a result an intellectual capabilities of humanity is elevated. Thus myths and modern novels do make similarity among them due to the aspect to happen a very intellectual consequence.

Another reason why myths turn to be an object of modern novels can be the following «On the basis of any myth there are concrete things, hence the functions being implemented by these things do not represent reality. For example, a "flying horse". There are two real objects in these mythic figures, which are Horse and Wing. Both the things are concrete for an ancient person. But conjoining these two real things and implementation of a particular function result origination of a myth» [1, p. 198]. Thus, in their aspect to dispute on a precise object or event we can consider a myth to be closer to the life truth rather than other genres. Exactly this falls under the circle of impact of an imaginative literature and figural mentality. It is a fact that science bases on preciseness. However modern novels appear to resolve scientific achievements in imaginative form. Creation of correlation among these two separate concepts, if science recognizes and commented by real 
evidences, myth plays a role of literal resolution in the modern novelty. Even such rhetorical issues like creation of world and related regularities can find their imaginative literal resolution within modern novelties. «One cannot reveal an aspect of those innumerable myths being presented by the pioneer novelists and admiring us during last two centuries just frivolously evaluating them as avoiding reality. It is a fact and definite that novel writers do avoid reality and try to pass it over. But passing over does not mean its avoidance» [3, p. 187], - notes Albert Camue speaking on the novel genre. Moreover, myth enlarges author's imaginations and fantasy consequences in presentation of realistic opportunities as «.... without imagination realism itself will undoubtedly face dead alley. Even the best photo-snap avoid reality; even it also searches the scenery of combination of realism and imagination and gets snapped therein. Artsmen of spiritualy and artsmen of reality do find each other in the scenery, where reality and imagination are combined. Reality and imagination - are inseparable parts of single integrity» [3, p. 192].

Few amazing cases - presence of cases when myths getting very close to the truth and reality. «Even today's science is not capable to justify the compatibility of these cases to the truth of life» [4, p. 23]. As no matter how estimated, imagined and fantasized would be the aspiration for the knowledge in the myths they embrace striving of humanity for scientific resolution and conclusion, though barbaric, and this can be considered as initial stage of humanity towards path of truth. In this regard it would be expedient to evaluate myths as initial bud, domain and foundation of scientific approach. Exactly in modern novels there is a precise justified affinity in reference to a myth as a genre uniting regularities of imaginative literature and science. One can evidence a row of positive features of a myth enlarging and enhancing artistry of modern novelty: «Reference to a myth enlarges up-todate boundaries of the imaginative literature. A myth within imaginative literature creates innumerable suppositions for defining and, most important, for commenting the present by means of unlimited, everlasting imaginative jeopardy , innumerable comparisons and affinities» [6, p. 3].

Indeed, on the example of «Ohir zamon noshonalari» author finds a specific correlation between Greek mythical hero Cassandra's destiny and Philofey, and by these means succeeds to cross through the boundaries of time and territory within the novel: Philofey flies onto the sky present territorial boundaries would not limit him at all.

Moreover, mythic interpretation enhances novel's impressiveness. it can also be considered as one of the styles to return to the humanity their own creations in new paints, to sympathize in truth compatible with their rejections - by this means to affect stronger and faster to the minds of the nation, in this context to warn the humanity from age-old tragedies.

In order to deeply explain the peculiarity of the "New approach to the traditions" it is vital to reveal its originality. European writers of the last century regularly used and referred to a myth. They, usually, took a Greek mythic hero and plugged him into the circumstances familiar to the author, and made them to feel comfortable as if home within those surrender. But in such cases only denomination from myths remained only.... We need to get folklore closer to us, but not in the view to master the scenery of the folklore, but, indeed, just to enjoy its spotty and versatility" [5, p. 378]. We can evidence utilization and reference to a mythic imaginations and their literal mastering within works of new Uzbek writers as Omon Muhtor in his "Ffu", Ulugbek Hamdam's "Isyon va Itoat" (Rebellion and obedience), Isajon Sulton's "Boqiy darbadar" (Careless wandered) novels. Moreover, utilization of a specific interpretation of mythology in the works of such writers as Sh.Holmirzaev, U.Hoshimov, N.Eshonqulov, Sh.Butaev, A.Dilmurod and others.

\section{Conclusion}

As a conclusion we may say that a myth serves as a means for the author to reveal a row of his imaginative-literal aims within modern novelty.

\section{References:}

1. Aytmatov C (2001) Ohir zamon nishonalari. T.: Sharq, 2001.

2. Yokubov O (2001) Chingiz Aytmatovning falsafiy "vahiylari" (Chingiz Aytmatov's philosofical "confessions") // Aytmatov Ch. Ohir zamon nishonalari (Yields of the last day). -T.: Sharq, 2001. -pp.3-10. 


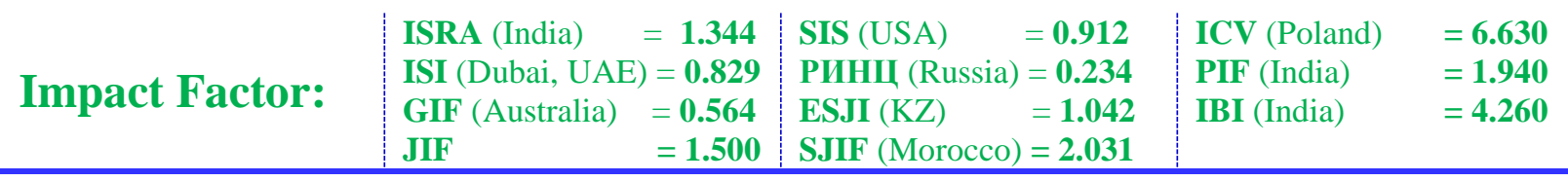

3. Camue A (1997) Isyon va sanyat. (Rebellion and obedience) // «Jahon adabiyoti», 1997, 1issue, 183-196 p.

4. Madaev O, Sobitova T (2001) Halq ogzaki poetic ijodi. -T.: Sharq, 2001.

5. Sulstade D (2010) Norway publication - Europe modernism / World men-of-letters about literature (Translation be Ozod Sharafiddinov) -T.: Manaviyat, 2010.

6. Holbekov M (2013) Hayot hoshiyasidagi bitiklar yohud «intellektual roman» hususida. (On life edge inscriptions either "intellectual novel") // Uzbekiston Adaboyoti va Sanati (Literature and Arts of Uzbekistan), 2013, October 18, №42.
7. Hotamov N, Sarimsoqov B (1983) RussianUzbek Explanatory dictionary of literal terms. T.: Uqituvchi, 1983.

8. Altybaeva SM (2008) Aktual'nye voprosy mifopoeticheskogo analiza // Vestnik Kazakhskogo natsional'nogo universiteta im. al'-Farabi. Seriya filologicheskaya. - Almata, 2008. - №1 (109). - pp.23-26.

9. Kostyukhin EA (1971) Aleksandr Makedonskiy v literaturnoy i fol'klornoy traditsii. -Moscow: Nauka, 1971

10. Mann T (1991) Iosif i ego brat'ya. V 2-kh t. Moscow, 1991. 